\title{
MANAJEMEN PEMENUHAN KEBUTUHAN ANAK DI KELUARGA DALAM PERSPEKTIF GENDER
}

\author{
Syaiful Marwan ${ }^{1}$ \\ Institut Agama Islam Negeri Batusangkar \\ syaifulmarwan@iainbatusangkar.ac.id \\ Himyar Pasrizal ${ }^{2}$ \\ Institut Agama Islam Negeri Batusangkar \\ himyar.pasrizal@iainbatusangkar.ac.id
}

\begin{abstract}
Every family member has different needs from one another. Children are the most important members of the family, especially in completing their needs. Each child has different basic needs. In the case of gender, sometimes boys are often prioritized over girls. But on the other hand girls also have many needs related to their nature as women. This various cases cause different need compliance that requires parents' consideration. Therefore, parents need to accommodate their children needs which have gender diversity. In managing these children's needs, parents' creativity and understanding of their children are needed.
\end{abstract}

Keywords: Management, Children's Needs, Family and Gender

\section{PENDAHULUAN}

Perubahan paradigm zaman ikut andil terhadap perubahan struktur dan fungsi keluarga. Olah et al., (2014) mengungkapkan bahwa berdasarkan studi gender dalam waktu yang lama, di dapat data bahwa telah terjadi perubahan struktur dan peran gender dalam keluarga. Masyarakat Indonesia adalah masyarakat yang terdiri dari berbagai tipe keluarga yang hidup dan menetap dalam menjalankan kehidupannya. Dalam keluarga tersebut memiliki anggota yang terdiri dari ayah, ibu, dan anak. Dalam hal ini, anak adalah aset terpenting dalam sebuah keluarga. Sebagai aset yang berharga biasanya harus dijaga dan dipelihara dengan baik. Anak menjadi anugrah terbesar orang tua yang memilikinya. Sehingga apapun yang diinginkan anak, orang tua selalu menyiapkan segala kebutuhan dan keinginan dari si anak.

Perkembangan kebutuhan masyarakat secara umum memperlihatkan kebutuhan utama yang harus dipenuhi adalah dimulai di lingkungan keluarga. Di lingkungan keluarga, anak-anak prioritas utama dalam keluarga. Untuk memenuhi kebutuhannya diperlukan adanya pemahaman terkait dasar pokok kebutuhan yang dimilikinya.

Sesuai dengan hal di atas, dapat dikatakan juga bahwa di Indonesia yang mana usia nonproduktif atau anak-anak berdasarkan data BPS pada tahun 2019 ada sebanyak 66,17 juta jiwa atau $24,8 \%$, yang artinya jumlah anak dari jumlah populasi. Hal ini memperlihatkan sebanyak 24,8\% adalah tanggungan keluarga yang memiliki anak yang harus ditanggung dan dipenuhi kebutuhannya. Kebutuhan yang beragam juga membuat hal ini dipandang rumit bagi orang tua yang memikirkannya, terkait tentang bagaimana cara memenuhi kebutuhannnya. Kebutuhan yang beragam tersebut juga dipengaruhi oleh keragaman gender anak. Ada yang memiliki anak lakilaki dan ada yang memiliki anak yang perempuan. Dalam kasus ini, orang tua justru menjadi rumit dalam upaya pemenuhan kebutuhan anak, yang mana 
anak laki-laki dan perempuan tidaklah sama kebutuhannya.

Dalam perspektif gender tersebut, anak laki-laki terkadang lebih diprioritaskan dalam upaya pemenuhan kebutuhannya karena dianggap sebagai penerus keluarga dan menjadi kepala rumah tangga kelak bila telah dewasa. Anak perempuan menjadi kurang diperhatikan karena nantinya dalam pandangan masyarakat, ujung-ujungnya dianggap akan ke dapur juga. Dalam kasus lainnya anak perempuan sering didiskriminasikan dalam upaya pemenuhan kebutuhannya. Masyarakat melihat dalam status sosialnya perempuan dianggap lebih rendah dari laki-laki. Dalam hal ini, laki-laki dianggap kuat, sedangkan perempuan dianggap lemah. Kelemahan tersebut dianggap menjadi dasar berfikir masyarakat secara umum, bahwa tidak banyak yang dibutuhkan oleh anak perempuan daripada laki-laki.

Dalam prinsip keadilan dan kesetaraan gender, kasus tersebut menjadi hal yang menjadi bahan perhatian. Untuk mengkaji lebih jauh sekiranya penting, dalam kajian ekonomi memperhatikan kebutuhan pokok anak dalam konteks primer dan sekundernya. Dengan melihat kebutuhan pokoknya tersebut, secara ekonomis maka akan terlihat hal apa saja yang dibutuhkan oleh anak, yang khususnya masing-masing anak laki-laki dan perempuan. Sehingga, dengan demikian memanajemen kebutuhan anak dapat terealisasi.

\section{PEMBAHASAN}

\section{Manajemen Kebutuhan}

Manajemen dapat diartikan merupakan seni menyelesaikan pekerjaan melalui orang lain. Hal ini sesuai dengan pendapat Griffin (2006), yang menjelaskan manajemen sebagai sebuah proses perencanaan, pengorganisasian, pengkoordinasian, dan pengontrolan sumber daya untuk mencapai sasaran secara efektif dan efisien. Efektif yang dimaksud adalah tujuan yang dicapai sesuai dengan perencanaan, sementara efesien berarti bahwa tugas yang ada dilaksanakan secara benar, terorganisir, dan sesuai dengan jadwal. Manajemen dalam pengertian lain menurut Afandi (2017) adalah bekerja dengan orang-orang untuk mencapai tujuan organisasi dengan pelaksanaan fungsi perencanaan (planning), pengorganisasian (organizing), Penyusunan personalia (staffing), penagarahan dan kepemimpinan (leading), pengawasan (controlling).

Dari dua pengertian tersebut terlihat perbedaan pada pengertian yang kedua dan mengarah kepada fungsi dari manajemen tersebut yang dapat dibagi sebagai berikut (Afandi, 2017): (1) Planning, Planning atau perencanaan merupakan pemilihan atau penetapan tujuan-tujuan organisasi dan penentuan strategi kebijaksanaan proyek program prosedur metode sistem anggaran dan standar yang dibutuhkan untuk mencapai tujuan. (2) Organizing, Organizing atau pengorganisasian adalah bentuk perancangan dan pengembangan suatu organisasi atau kelompok kerja yang akan dapat membawa hal-hal tersebut ke arah tujuan. (3) Staffing, Staffing atau penyusunan personalia adalah bentuk penarikan, latihan dan pengembangan serta penempatan dalam pemberian orientasi pada orang-orang yang akan bekerja dalam lingkungan yang menguntungkan dan produktif. (4) Leading, Leading atau fungsi pengarahan adalah bagaimana membuat atau mendapatkan manusia yang melakukan apa yang diinginkan dan harus mereka lakukan. (5) Controlling, Controlling atau pengawasan adalah penemuan dan penerapan cara dan alat untuk menjamin bahwa rencana telah dilaksanakan sesuai dengan apa yang telah ditetapkan.

Dengan fungsi manajemen tersebut dapat dikatakan mengarah kepada pengelolaan dalam proses perencanaan dan perbaikan sebagai upaya mencapai tujuan secara maksima. Dengan demikian perencanaan dan perbaikan tersebut 
menjadikan apa yang hendak dicapai terlaksana secara terukur.

Sebelum melihat bagaimana manajemen kebutuhan, perlu diketahui mengenai kebutuhan. Kebutuhan dalam Kamus Besar Bahasa Indonesia (KBBI) diartikan adalah yang dibutuhkan. Artinya jika dikaitkan dengankebutuhan manusia bahwa, segala sesuatu yang dibutuhkan oleh manusia dalam rangka memenuhi kebutuhannya untuk hidup. Hal ini sesuai dengan hipotesa Maslow (1993), yang menjelaskan tingkatan kebutuhan, yang diantaranya sebagai berikut: (1) Kebutuhan fisiologis, termasuk lapar, haus tempat berteduh, seks dan kebutuhan badaniah lainnya. (2) Kebutuhan akan rasa aman, termasuk keamanan dan perlindungan terhadap gangguan fisik serta emosional. (3) Kebutuhan sosial, termasuk kasih sayang, penerimaan oleh masyarakat, keanggotaan kelompok dan kesetiakawanan. (4) Kebutuhan akan penghargaan, termasuk harga diri, kemandirian, keberhasilan status, pengakuan dan perhatian. (5) Kebutuhan akan aktualisasi diri, termasuk kemampuan mencapai sesuatu, kemampuan berkembang, kemampuan mencukupi diri sendiri.

Dari hipotesa Maslow (1993) tersebut, dapat disimpulkan bahwa manusia secara mendasar memiliki banyak kebutuhan dasar, diantaranya seperti kebutuhan yang bersifat fisiologis, kebutuhan akan rasa aman, kebutuhan akan kehidupan sosial atau berinteraksi dengan orang lain, kebutuhan mendapat penghargaan, dan kebutuhan untuk mengaktualisasikan diri dengan lingkungannya.

Selain itu dalam teori Existence, Relationees, dan Growth needs (ERG), kebutuhan juga dijelaskan Aldefer (1985), yang berasumsi; (1) Apabila kebutuhan keberadaan kurang terpenuhi, individu terdorong untuk memenuhi kebutuhan tersebut, (2) Apabila kebutuhan berhubungan dengan orang lain kurang terpenuhi maka individu terdorong untuk memenuhinya, (3) Apabila kebutuhan akan pertumbuhan kurang terpenuhi maka makin besar hasrat untuk memenuhi kebutuhan akan pertumbuhan tersebut. Dalam teori tersebut bahwa kebutuhan muncul karena adanya keinginan untuk diakui oleh orang lain mengenai keberadaannya dalam lingkungannya tempat ia hidup. Kemudian kebutuhan juga muncul karena adanya keinginan untuk berinteraksi sosial dengan orang lain. Selajutnya dapat dikatakan bahwa kebutuhan juga bisa muncul, dikarenakan adanya keinginan tumbuh dan perkembang dalam perkembangan waktu yang dialaminya.

Jika dikaitkan antara manajemen dan kebutuhan maka dapat diartikan bahwa segala sesuatu kebutuhan individu dapat dicapai dengan dangan perencanaan yang telah dikelola dengan. Hal ini sesuai dengan dengan pengertian manajemen kebutuhan yang menjelaskan, manajemen kebutuhan (Artina, 2006) adalah pendekatan sistematis untuk mendapatkan, mendokumentasikan, mengatur dan melacak perubahan kebutuhan. Hal ini dapat dikatakan bahwa kebutuhan yang diinginkan dapat dikelola sehingga tujuan dapat tercapai secara efektif dan efisien.

\section{Kebutuhan Anak dalam Perspektif Gender}

Istilah gender, sering diidentikan kepada perbedaan jenis kelamin. Gender menurut (Udry,1994) adalah serangkaian karakteristik yang terikat kepada dan membedakan maskulinitas dan femininitas. Karakeristik tersebut dapat mencakup jenis kelamin (laki-laki, perempuan, atau interseks), hal yang ditentukan berdasarkan jenis kelamin (struktur sosial seperti peran gender), atau identitas gender. Hal ini diartikan bahwa gender menyatakan perbedaan perbedaan jenis kelamin dalam berbagai bentuk secara mendasar yang terlihat dalam bentuk sikap dan tindakan. Pada tahun 2011, Food and Drug Administration (FDA) mulai menggunakan jenis kelamin/seks untuk klasifikasi biologis dan gender untuk "representasi" diri seseorang sebagai laki-laki atau perempuan 
atau bagaimana ia merespon terhadap institusi-institusi sosial yang didasarkan pada presentasi gender seseorang (FDA, 2011).

Dalam konteks kebutuhan, setiap jenis kelamin memiliki kebutuhan yang berbeda satu sama lain. Konsep gender lakilaki memiliki kebutuhan yang lebih maskulin, sedangan perempuan lebih memilih kebutuhan yang bersifat feminim. Namun secara umum berdasarkan kebutuhan yang dijabarkan dalam tingkatan kebutuhan oleh Maslow (1993), maka dapat dijabarkan terkait dalam pemenuhan kebutuhan anak adalah sebagai berikut:

\section{Kebutuhan Fisiologis}

Secara fisiologis anak laki-laki dan perempuan secara mendasar memiliki tingkat pemenuhan kebutuhan yang beragam, ada yang secara umum berbeda, dan ada secara spesifik juga yang berbeda. Dalam masa tumbuh kembang anak yang menjadi kebutuhan fisiologisnya (Kania, 2006: 2) diantaranya; (a) pangan (makan/minum)/gizi, (b) perawatan kesehatan dasar, (c) pengobatan, (d) pemukiman yang layak, (e) kebersihan perseorangan, sanitasi lingkungan, (f) pakaian, dan (g) kesegaran jasmani.

Sebagai contoh, dalam hal makan dan minum, setiap anak pada dasarnya mempunyai kebutuhan yang sama. Orang tua dalam hal ini tidak perlu khawati terhadap upaya pemenuhan kebutuhannya. Makan dan minum, sudah jelas ditentukan waktu dan kapan dipenuhinya, yakni ketika lapar dan haus. Oksigen adalah kebutuhan yang secara mendasar juga berguna untuk kelangsungan hidup. Hal ini pun juga bisa didapatkan oleh anak secara bebas. Namun secara khusus yang disebutkan bahwa terkait dengan gender atas keinginan seksual, ini memiliki masingmasing kebutuhan yang berbeda. Dalam perkembangan anak perempuan sebagai lahiriyahnya harus mengalami datang bulan, yang secara ekonomis akan menimbulkan kebutuhan lebih banyak untuk anak perempuan dalam menyiapkan obat dan pembalut terkait dengan anak perempuan tersebut. Hal ini tidak dialami anak laki-laki, sehingga terlihat perbedaan dalam pemenuhan kebutuhan anak laki-laki dalam hal tersebut, lebih sedikit dari anak perempuan.

2. Kebutuhan Akan Rasa Aman

Kebutuhan akan rasa aman dimiliki oleh setiap anak di dalam keluarga. Setiap anak, baik laki-laki dan perempuan memiliki keinginan agar selalu dilindungi oleh orang tua. Kebutuhan akan rasa aman ini adalah kebutuhan yang secara lumrah ada, karena anak secara mendasar dan belum mandiri memang harus dilindungi. Salah satu contohnya adalah rumah yang dianggap aman oleh si anak dan orang tua yang selalu sabar dan menunjukkan sikap protektif dalam mengayomi anak dalam keluarga. Dalam menujukkan sikap protektif terhadap anak, anak perempuan sangat sensitif dalam hal ini, akibatnya orang tua lebih banyak tuntutan dalam memberikan perlindungan dibandingkan anak laki-laki. Hal tersebut sesuai dengan pendapat Milheim (dalam Aini, 2016:3) menyatakan bahwa kebutuhan rasa aman harus dilihat dalam arti luas, tidak hanya dalam arti keamanan fisik, tetapi juga keamanan yang bersifat psikologis, seperti perlakuan yang manusiawi dan adil. Artinya sesuai dengan perbedaan gender.

3. Kebutuhan Sosial

Kebutuhan sosial adalah kebutuhan dasar manusia. Seseorang individu membutuhkan interaksi sosial dalam kehidupannya. Silvianetri (2019) mengungkapkan bahwa manusia melakukan interaksi dengan orang lain sejak kehadirannya di bumi. Interaksi sosial dengan orang lain akan berjalan 
efektif jika melibatkan pikiran dan perasaan. Seiring dengan perkembangannya, anak akan mengenal orang, maka muncul keinginan untuk berkomunikasi. Komunikasi yang pertama kali dilakukannya adalah dengan orang tua. Selanjutnya ketika menemukan orang lain yang sebaya maka si anak juga butuh dalam berinteraksi secara sosial. Hal ini sesuai dengan pendapat Aristoteles (Galih, 2017:6), yang mana manusia adalah makhluk sosial. Perihal dengan anak dalam konteks ini, dapat dikatakan anak butuh berinteraksi dalam kehidupan sosialnya. Secara gender, masingmasing anak memiliki pola interaksi yang berbeda. Mereka senang bergabung dengan kelompok dalam masa pra remaja (10-12 tahun) sesuai dengan jenis dan status yang sama (Gunarsa,1991:14). Anak perempuan berkelompok dengan jumlah yang relatif sedikit dibanding dengan anak laki-laki yang cendrung lebih banyak dalam berkelompok.

4. Kebutuhan Akan Penghargaan

Manusia butuh untuk dihargai. Kebutuhan ini dalam pandangan Maslow, muncul agar individu termotivasi dalam bertindak. Hal ini sudah terlihat pada masa kehidupan anak dalam perkembangannya. Anak akan merasa kebutuhannya terpenuhi jika semua tindakannya dihargai oleh orang tua dan lingkungannya. Dalam konteks gender, dapat dilihat bagaimana kebutuhan anak laki-laki dan perempuan memiliki cara berbeda untuk dihargai. Sebagai contoh, hadiah adalah salah satu wujud dari bentuk penghargaan. Seperti anak laki-laki yang membutuhkan mainan lebih maskulin, dan perempuan yang bersifat feminim. Contoh lainnya, bisa seperti ucapan balasan dari orang tua atas sikap dan perilaku yang ditampilkan si anak.

5. Kebutuhan Aktualisasi Diri
Kebutuhan untuk aktualisasi diri adalah bentuk kemampuan untuk berkembangan dalam menampilkan diri dalam masyarakat. Kemampuan ini pada dasarnya telah diberikan kepada orang tuanya sebelum masuk dalam lingkungan sosial bermasyarakat. dalam gender, masing-masing anak memiliki aktualisasi yang berbeda, sehingga kebutuhan akan beraktualisasi juga berbeda. Walaupun dengan perbedaan tersebut, selalu ada keinginan anak daan menjadi kebutuhannya sehingga dapat beraktivitas secara optimal. Hal tersebut sesuai dengan pendapat Schunk et.al. (Dalam Aini, 2016:4) menyatakan bahwa kebutuhan aktualisasi diri adalah suatu kebutuhan untuk mengoptimalkan potensi diri, suatu keinginan untuk menjadi apa yang dirasakan oleh individu karena mempunyai potensi mencapainya.

\section{Manajemen Kebutuhan Prioritas Anak Sesuai Gender}

Pada dasarnya, dalam memanajemen kebutuhan anak adalah tanggungjawab dari orang tua. Orang tua adalah kepala organisasi terkecil yang dicontohkan dalam bentuk keluarga. Dalam keluarga, anak dipersiapkan untuk menjalani tingkatantingkatan perkembangannya sebagai bekal ketika memasuki dunia orang dewasa, bahasa, adat istiadat dan seluruh isi kebudayaan, seharusnya menjadi tugas yang dikerjakan keluarga dan masyarakat di dalam mempertahankan kehidupan oleh keluarga (Soemarjan, 1962:127)

Dalam memanajemen kebutuhan anakanak dalam keluarga perlu dengan prinsip dan fungsi manajemen. Hal ini dapat dikaitkan dalam fungsi manajemen dan kebutuhan anak yang ada pada pembahasan sebelumnya di atas maka akan dapat dijabarkan sebagai berikut:

\section{Planning}

Pada tahapan perencanaan ini adalah tahapan orang tua berfikir dengan menyiapkan anaknya untuk masa 
depannya. Hal yang direncanakan orang tua adalah terkait dengan masingmasing anak secara gender, yang memiliki tujuan yang berbeda satu sama lain. Dengan demikian strategi yang digunakan juga harus berbeda satu sama lain, namun dengan prinsip semua kebutuhan anak terpenuhi dengan strategi dan perencanaan yang telah disusun.

2. Organizing

Pada tahapan ini adalah bentuk perancangan model yang disusun dan pengembangan yang dilakukan oleh orang tua. Dalam implemtasinya, orang tua merancang dengan melihat kebutuhan yang dimiliki masing-masing anak mau dijadikan apa anak setelah dewasa kelak. Anak laki-laki akan dibentuk sesuai dengan maskulinitasnya, seperti contoh anak laki-laki yang dipersiapkan menjadi calon tantara dan contoh lainnya. Selain itu, anak perempuan akan dibentuk pula sesuai dengan feminimitasnya. Sebagai contoh, anak perempuan menjadi perawat dan contoh lainnya.

3. Staffing

Pada fungsi ini adalah bagaimana orang tua membagi tugas perkait dengan perannya secara gender. Bagaimana peran ayah dan bagaimana peran ibu di dalam keluarga. Kedua orang tua tersebut mempunyai peran yang berbeda yang secara mendasar menjadi pekerja di bidangnya dalam memenuhi kebutuhan anak. Sebagai contoh ibu yang dalam mengayomi anak di dalam rumah dan memantau perkembangan masing-masing anak. Ayah dalam pandangan umum bertugas dalam mencari nafkah. Namun, dalam era milenial sekarang bahkan dalam posisi seperti tersebut bisa terbalik, karena adanya kesetaraan gender. Masingmasing orang tua bisa berkolaborasi satu sama lain dalam melaksanakan perannya di dalam keluarga.

\section{Leading}

Dalam fungsi ini, ayah menjadi sosok sentral dalam memimpin pelaksanaan memanajemen keluarga. Namun yang banyak sebagai menejer keluarga banyak dilakukan oleh ibu dalam pandangan umum masyarakat. Ayah menjadi tauladan dan sosok yang dicontoh oleh anak laki-laki dalam tumbuh kembangnya. Namun disisi lain ibu juga menjadi sosok tauladan juga kepada anak perempuannya. Dengan demikian kedua orang tua bisa menjadi tauladan kepada masing-masing anaknya secara gender.

\section{Controlling}

Dalam hal mengontrol pelaksanaan memanajemen anak-anak, kedua orang tua mempunyai tugas yang sama, apakah anak sudah menjalankan pendidikan sesuai dengan perencanaan yang telah disusun sebelumnya. Masing-masing anak harus diawasi oleh kedua orang tua, sehingga apa yang telah dirancang dan akan dikembangkan dalam upaya pemenuhan kebutuhan anak secara gender dapat terpenuhi.

\section{KESIMPULAN DAN REKOMENDASI}

Ada beberapa kesimpulan dalam artikel ini, yaitu; (1) kebutuhan setiap anak dalam keluarga berbeda-beda, (2) dalam upaya pemenuhan kebutuhan anak berdasarkan perspektif gender membutuhkan manajemen yang jelas dan terencana dengan baik. (3) Prinsip pemenuhan kebutuhan adalah berdasarkan keadilan. Adanya perbedaan gender yang dimiliki oleh masing-masing anak menjadi hal yang menjadi dasar berfikir orang tua dalam menyiapkan berbagai pola pemenuhan kebutuhan anak. Penyiapan kebutuhan berdasarkan prinsip keadilan. Adil yang dimaksudkan adalah mengutamakan kebutuhan anak bukan memberikan sesuatu dengan pertimbangan jenis kelamin anak.

Artikel ini merekomendasikan kepada orang tua, pemenuhan kebutuhan 
anak yang berbeda ini dapat dikelola dengan dengan baik secara adil, efektif dan efisien. Sehingga masing-masing anak merasa dapat dukungan psikologis yang sama dari orang tuannya.

\section{DAFTAR KEPUSTAKAAN}

Afandi, Pandi (2018). Manajemen Sumber Daya Manusia: Teori, Konsep dan Indikator. Zanafa Publishing. Pekanbaru

Artina, Nyimas. (2006). Penerapan Analisis Kebutuhan Metode Use Case pada Metode Pengembangan terstruktur. Jurnal Ilmiah STMIKGI MDP.Vol. 2, No. 3. Hal:1-6

Aini, D. F. N., Hanurawan, F., \& Hariyono, H. (2016). Pengembangan Motivasi Belajar Siswa Berprestasi Anak Tenaga Kerja Indonesia (Studi Kasus pada Siswa Sekolah Dasar di Kabupaten Blitar). Jurnal Pendidikan: Teori, Penelitian, dan Pengembangan, 1(9), 1875-1879.

Badan Pengawas Obat dan Makanan Amerika Serikat (2011-12-19). "Draft Guidance for Industry and Food and Drug Administration Staff Evaluation of Sex Differences in Medical Device Clinical Studies", online. Diakses tanggal 2019-11-02.

Galih, Y. S. (2017). Kewajiban Negara Melindungi Anak Bangsa. Jurnal Ilmiah Galuh Justisi, 5(1), 113-133.

Gunarsa, S. D. (1991). Psikologi praktis: anak, remaja dan keluarga. BPK Gunung Mulia.

Griffin, R. (2006). Business, $8^{\text {th }}$ Edition.NJ: Prentice Hall

Hadi, S. (1985). Manajemen Sumber Daya Manusia I. mercubuana.ac.id

Kania, N. (2006). Stimulasi tumbuh kembang anak untuk mencapai tumbuh kembang yang optimal. In
Seminar Stimulasi Tumbuh Kembang, Bandung (Vol. 11).

Maslow, A.H. (1943). "A Theory of Human Motivation". Psychological Review. 50 (4): 370-96

Mursidin, Mujahidin dan Suriadi. (2018). "Character Education Based on Gender Justice in The Islamic Perspective". Al-hayat: Journal of Islamic Education (AJIE). Vol. 2, Issue 2. Hal:202-2012.

Mawadah, AH. (2018). "Nilai Kesetaraan Gender Pada Cerpen Dalam Buku Teks Bahasa Indonesia Sma”. LITERA Vol. 17, No.1. Hal:30-40

Olah, L.S. Richter, R \& Kotowska, I.E. (2014). The new roles of men and women and implications for families and societies. Families and Societies Working Paper, (11), 1-21

Puspitawati, H. (2013). Fungsi Keluarga, Pembagian Peran Dan Kemitraan Gender Dalam Keluarga. Departemen Ilmu Keluarga dan Konsumen Fakultas Ekologi Manusia IPB.

Puspitawati, H, DH, dan TH (2018). "Pengaruh Pola Asuh Disiplin Dan Pola Asuh Spiritual Ibu Terhadap Karakter Anak Usia Sekolah Dasar”. Jurnal Pendidikan Karakter, Th V, No.2. Hal:208-2018.

Sada, H. J. (2017). Kebutuhan dasar manusia dalam perspektif pendidikan Islam. Al-Tadzkiyyah: Jurnal Pendidikan Islam, 8(2), 213-226.

Silvianetri.2019. Interpersonal Skill Dalam Kajian Neurosains. Alfuad Journal, 3 (1), 74-81.

Soemarjan, Selo. (1962). Sosiologi Suatu Pengantar. Gajah Mada Press. Yogyakarta

Udry, J. R. (1994). "The Nature of Gender". Demography. 31 (4): 561-573. 